\title{
The Status of Woman in the plays of Vijay Tendulkar's Ghashiram Kotwal and Kamala
}

\author{
S Sulekha Rani, Prof. P. Padma \\ ${ }^{1}$ Research Scholar, Dept of English, Rayalaseema University, Kurnoo, AP, India \\ ${ }^{2}$ Professor, Dept. of English, Yogi Vemana University, Kadapa, A.P, India
}

\begin{abstract}
Indian society divided into castes which are fairly homogenous patriarchal culture developed. Hindu society, which is a high reverence to women as mother, evolved social norms and rituals which constantly emphasis a woman's role as one of service to all male members of the family whether it be father, husband (or) son.

The culture and civilization of a human creates new needs which brings new roles. In their life time everyone will plays different roles, no man is completely good (or) bad. Anthropological studies Proves that criminal behavior of the people is also a product of culture. Gamst \& Norbeck point of view, personality is largely a mirror of culture. One's personality is a complex product of the interaction of many roles. In this way they grow de humanized as they learn playing their games in the roles.
\end{abstract}

Keywords- Indian Society- patriarchal- culturecivilization.

\section{INTRODUCTION}

Tendulkar's Ghashiram Kotwal is a very good example how we lose track to obtain power. This play illustrates the oppression and exploitation of women by men in patriarchal society. The eponymous character, Ghashiram, sells his own daughter to lustful Nana in order to buy poor as the Kotwal of Poona to take his revenge on the people of Poona. Nana, the Chief Admin istrator of Peshva, makes use of his power to enjoy sex with the women of his choice. He exploits Lalitha Gouri, Ghashiram's daughter, and gets her killed when she becomes pregnant through crude method of abortion. As everybody is afraid of Nana's power, nobody dares to stop him and the Brahmans of Poona, like Appana of Karnad's Naga-Mandala shut their wives in and visit the Bavannakhani. The only aim of Ghashiram is to suppress Brah mans of Poona with his power, to gain that power he exploit Nana through flattery by hold ing his sprained foot in his hands. When Ghashiram was immensely hurt and humiliated by Poona Brahmins, he decided to take revenge on them.
In Kamala, Jai Singh Jadav is a brilliant and brave journalist who takes risk, exposes the scandals and feed the paper with sensational news. Because of him, the paper circulation has increased and the proprietors hikes his salary. He feels happy and encouraged and takes much more risky tasks. Made a well-furnished home. His wife Sarita takes care of all his need at home. She satisfies him in all aspects. Sarita is obedient to him while her husband is obedient to his superior. In his Sarita plays a typical wife, yet Jai Singh never tries to honor her word, then slowly Sarita realizes how she has been suppressed and exploited.

\section{MAJOR CONCEPT}

Here, in this context, Ghashiram's hatred for the people of Poona overwhelms, overpowers his love for his daughter. So he suppresses his love and his affection for his daughter to suppress and exploit the people of Poona. After surrendering his daughter he acts as a persecutor. Sanik in the "Introduction" comments: "Tendulkar suggest the sexuality implicit in power in the brilliant innuendo that caps the situation. Ghanshiram exploits Nana's lust and his innocent daughter, Gouri, in acquiring power. Sex for Nana, is not only a source of enjoyment but also an effective way of displaying his power while violence serves the same purpose for Ghashiram as quoted in the epigraph, Ghashiram needs an official title, the Kotwalship, to be the persecutor, in order to feel powerful thus overcome his powerlessness.

Sanik explains how Nana exercises his power safety through Ghashiram. He uses Ghashiram as a tool in exploiting the people of Poona finally Ghashiram the persecutor of the people of Poona is ruthlessly and mercilessly humiliated by the revolted people and is also murdered by them. Sanik therefore, observes but in the shifting game of power it is temporary adjustment that Nana exploits as long as necessary and can drop unceremoniously the moment it has served its purpose. By using his power Ghashiram wants to get his daughter married. But unfortunately Gouri dies as the midwife cruds attempts to effect abortion. The revolted Ghashiram murderously approaches Nana. Nana feels frightened and 
started to praise his works as the Kotwal and also reminds him of this superiority. He quotes from scriptures and advises him to forget the past. Like the people of the higher ranks of the society, Nana uses religious ideology to justify the hierarchy of power and the unjust oppression and exploitation. Nana advises Ghashiram to use his power to shut the mouths of the people trying to talk ill about his daughter. Ghashiram is convinced and accepts his daughter's death since he can continue to exercise his power. Thus, Nana cleverly manages in quientening Ghashiram.

Ghashiram uses his immense power effectively in the city of Poona. After his daughter's death the feeling of powerlessness still haunts him and in his frenzy he starts murdering people. The situation becomes grave when the matter comes to the notice of Peshwa. By understanding the grave situation, Nana issues them the order to kill Ghashiram mercilessly. So, Nana has exploited Ghashiram treacherously.

So, women are suppressed and exploited in various ways. The innocence of Rani in Naga-Mandala and the affectionate daughter Gouri has been exploited.

In Kamala, Jai Singh Jadav is obedient to his employer and the employer is obedient to the superiors. Sarita, the sophisticated wife is obedient to her husband just as in kamala, in the play Gharshiram Kotwal, nana is obedient to Peshva, Ghashiram is obedient to Nana and Gowri is obedient to her father they find each other mysterious and impetus to the exploitation and suppression of some people by others. Vijay Tendulkar's Kamala, elucidate this predicament of a man and women. The play Wright is inspired in writing this play by a real life incident in the Indian express by Ashwin Sarin, a journalist, who really bought a woman in a rural flesh market and presented her at a press conference to expose the inhuman flesh trade.

In the play Kamala also picturises the same as we see in Ghashiram Kotwal. Jai Singh goes to Laherdaga beyond Ranchi in Bihar and buys Kamala Rs.250/ - at flesh market, even a bullock costs more than that.

The largest concentration of the world's poor lies in South Asia more than seventy percent of the poor are women, who suffer from higher than average mobility and lower levels of education. Many of them do not have access to have drinking water and proper sanitation. They are neglected, mute and desolate they are bound with a fatal chain. In this made dominated society women like kamala becomes a lifeless commodity. In our country where wo man are worshipped and praised, the flesh trade is going on. Women are treated inhumanly. Society is suppressing this gender and exploiting them in various ways wo men are tongue tied. Such wo men have lost their spontaneity and yielded to adaptability. In Naga Mandala, Rani is yielded to her dominant husband, kamala is also suffered with slavery and Sarita suppress all here emotions and yielded to adaptability in this patriarchal society. Gouri is denied of individuality in Ghashiram Kotwal, Leela Benare is denied of freedom in the play, silence! The court is in session women are suppressed in many ways.

Tendulkar perceives the realities of the human society without any Pre-conceived notions. Reacts to them as a sensitive and sensible human being and writes about them in his plays as responsible writer.'They contain my perceptions of society and its value \& I can't write what I do not perceive " $(71)$. He depicts the violent tendency of egotistical man \& equally self centered society. Tendulkar explores the positing of women in contemporary Indian Society.

Intrinsic in the modern Indian male who believes himself to be liberal - minded like kamala. Sarita is also an object in Jadav's wife, an object that provides physical enjoyment, social companion ship and domestic comforts. Kamala's entry into the household reveals to Sarita, the selfish hypocrisy of her husband and insignificance of her own existence, yet, like most of Tendulkar's sympathetic women characters, she does not have the spirit to rebel against her present condition.

Kaka Sahib, Sarita's uncle who runs a news paper in his home town, arrest the predicament of Jai Singh. He warns him of the possible future danger. This proves later but Jai Singh ignores it. He succeeds at the press conference in exposing the inhuman flesh trade by presenting kamala as a proof. When kamala is asked certain unpleasant questions there Jai Singh fails to understand her feelings and embarrassment as he lacks intuition. In his view women are only objects without any feelings. Sarita who feels sorry for kamala and the nurturing parent in her took pity on kamala. Kamala thinks innocently that all women are slaves like her, irrespective of their social status. Even she asks to Sarita that "How much did he buy you for" (34). Sarita shocks to listen that question and realizes her real position in that house. Then she says that Jai Singh bought her for "seven hundred". Then kamala replies, it was an expensive bargain"(34) and she proposes that she will do all the house work, while Sarita can look after accounts and such sophisticated things, she also says that each of them will share their master's bed half a month each, Sarita agrees to it and realizes that is also a sophisticated slave. We can see persecution of women and the faculty of ugliness. That is suppression and exploitation. She shares her 
thoughts to Kaka sahib, how her slavery is reminded by kamala.

Sarita's agony is the agony of all women. No difference is seen between a sophisticated Sarita and illiterate kamala. These two wo men are used by Jai Singh to obtain power. He exploits kamala's poverty and innocence and at the same time he exploits Sarita's care and concern towards him. His only aim is to get compliments. Later when the police are at his back he plans to keep kamala in orphanage. But kind hearted Sarita requests him to allow her to live with them when Jai Singh has been sacked from his job, his ego is suppressed by his proprietor, where as the proprietor's ego is suppressed by the big people in flesh trade. Tendulkar himself says that "Kamala after a time becomes a symbol, the wife of the journalist becomes" kamala, and ultimately even he (the journalist) becomes "kamala"(25). At the end of the play Sarita realizes her position in the house as a slave and she wants to revolt against her husband.

But M.Sarat Babu says that it can also be concluded that is an indictment of the business oriented capital dominate society where men like Jai Singh are victims or stepping stones in a capitalist's success women are oppressed and exploited more than man in society as it remains culturally patriarchal in spite of democracy. Ambedkar points out, "A Woman under the laws of Manu is subject to corporal punishment and Manu allows the husband the right to beat his wife"(9). Indian society which has accepted the laws of manner denies education to wo men and approves caporal punishment in addition to humiliating vituperative verbal attacks on them, when a gentle man objects to the beating of a woman by her husband; he says that he has a right to do this to his wife whatever he likes. In the modern era the educated women are also yielding to the domination of patriarchal society. That is how women are suppressed.

In primitive times human beings felt that they were powerless and inferior because they, having become aware of their own identity, alienated themselves from nature. They have been striving to become powerful and superior since men. As civilization progressed, the alienation entered human society and caused various division of it. Then their strong desire to become more powerful than one another, are to suppress one another and to exploit another hierarchies those divisions. This has made the society pyramidical where die few at the top usurp the great power of the males at die bottom. This has become possible and usual because the people give away their power by taking the hierarchized society for granted.

\section{CONCLUSION}

To be obedient man and women, they develop the faculty of adaptation to culture. Owing to their suppression of the faculty of spontaneity, both of them are unable to enjoy life. Tendulkar's silence! The Court is in session and Karnad's Naga - Mandla questions the gender- biased justice, which favours man. Appana's behavior with Rani in a rude way without any compassion exemplifies this. He openly goes to his concubine regularly and unashamedly No. Village elder question him, while Rani is urged by her husband to prove her charity. Village elders ask her to take an ordered to prove her chastity. But Appanna is not asked to take an order to prove his faithfulness to his wife.

In their madness of scrambling to the top of the hierarchies society, people become dehumanized. This deformity makes them loveless. Hence, they ruthlessly suppress and exploit their fellow human beings. A wo man works hard and serves all the people of her husband's house. She is the first to wake up and the last to go to bed. She, with her faculties of nurturing and intuition, looks after her husband's family with utmost care. She does not receive due recognition for her service let alone remuneration. She bears the pregnancy of her husband without demanding any compensation for her pains. Her erotic stratification is confined to her reproductive role while her husband is conventionally allowed to seek ext ra marital erotic pleasures. She has no rights. She remains helpless. Thus, in our patriarchal society, women are suppressed and exploited.

All the world's a stage

And all the men and women merely players.

\section{--- Shakespeare}

\section{REFERENCES}

[1] Tendulkar, Vijay (1984), 'Introduction', Ghashiram Kotwal. Calcutta: Seagull, p.v.

[2] Tendulkar, Vijay (1994), 'Authors Introduction', to Three Plays. Delhi: Oxford University Press, p. 18.

[3] Tendulkar, Vijay (2004), Ghashiram Kotwal, with Introduction and Notes by Nandana Datta. New Delhi: Oxford University Press, P. 36 (All subsequent quotations are from this edition of text, and are indicated by page number/s in parenthesis.)

[4] Karnad, Girish, in Ramnarayan Gawri, " A New Myth of Sysyphus": (Vijay Tendulkar and Girish Karnd in conversation with Gowri Ramnarayan), The Hindu folio on theater, Feb. 1998, p. 14-15

[5] Tendulkar, Vijay, 'Interview, India Today, Dec. 1631, 1980, p.157. 
[6] Babu, M. Sarat, 2003, 'Introduction', Ghashiram Kotwal : Readers Campion. New Delhi : Asia Book Club, P.77

[7] Karnad, Girish, (1994), in 'Author's Introduction', Three plays. Delhi : Oxford University Press, p. 15.

[8] Barry, Peter. Beginning Theory: an introduction to literary and cultural theory. Manchester University Press. 2004.

[9] De,Beauvoir,Simone. The Second Sex. Trans. And ed. H.M. Parshley, 1953;rpt. Harmonds worth:Penguin,1977

[10] Tendulkar, Vijay. A Testament, in Indian Literature no. 147, January-February 1992,

[11] Tendulkar, Vijay. Collected Plays in Translation. Oxford University Press.. 2003. 